\title{
HUBUNGAN TINGKAT PENGETAHUAN MAHASISWA ASRAMA PUTRA UNIVERSITAS ADVENT INDONESIA TENTANG TB PARU TERHADAP STIGMA PENDERITA TB PARU
}

\author{
Daniel Sihotang, Imanuel Sri Mei Wulandari \\ Fakultas Ilmu Keperawatan Universitas Advent Indonesia, Bandung, Indonesia \\ Email: danielsihotang88@gmail.com, ari.imanuel@unai.edu
}

\begin{abstract}
Mycobacterium tuberculosis is a cause of tuberculosis which is very easily transmitted from one individual to another. This bacterium is easily spread through droplets that come out with a patient cough, this makes Lung Tuberculosis included in the 10 causes of death in the world beyond HIV / AIDS. The purpose of this study was to determine the relationship between students' knowledge and stigma against Tuberculosis. The method used in this study is descriptive correlation with cross-sectional, data collection techniques with a total sampling of 139 students. Statistical treatment employed in the study was Spearman's correlation analysis with a significance of $95 \%$ ( $<0.05)$. The results obtained by the level of student knowledge of Lung Tuberculosis in the moderate category (70.5\%), the stigma of students towards tuberculosis patients $64 \%$ have a negative stigma against Tuberculosis. Correlation test between knowledge and student stigma has a $p$ value of $0.009<0.05$, this means that there is a significant relationship between knowledge and student stigma against Tuberculosis. The recommendations given are increasing knowledge for the prevention of tuberculosis.
\end{abstract}

KeyWord: Knowledge, Stigma, Tuberculosis,

\begin{abstract}
ABSTRAK
Mycobacterium tuberculosis merupakan penyebab terjadinya penyakit tuberkulosis yang sangat mudah menular dari individu satu ke individu lainya. Bakteri ini mudah sekali menyebar melalui droplet yang keluar bersama batuk penderita, hal ini membuat Tuberkulosis Paru termasuk dalam 10 penyebab kematian di dunia melebihi HIV/AIDS. Tujuan dari penelitian ini adalah untuk mengetahui hubungan antara pengetahuan dan stigma mahasiswa terhadap Tuberkulosis. Metode yang digunakan dalam penelitian ini adalah deskriftif korelasi dengan pendekan cross sectional, teknik pengumpulan data dengan total sampling pada 139 mahasiswa. Analisa data dengan menggunakan uji korelasi spearman rho dengan signifikansi $95 \%(<0.05)$. Hasil penelitian yang didapatkan tingkat pengetahuan mahasiswa terhadap Tuberkulosis Paru pada kategori sedang $(70,5 \%)$, stigma mahasiswa terhadap penderita TBC $64 \%$ mempunyai stigma negatif terhadap Tuberkulosis. Uji korelasi antara pengetahuan dengan stigma mahasiswa mempunyai nilai p $0,009<0,05$, hal ini mempunyai arti terdapat hubungan yang signifikan antar pengetahuan dengan stigma mahasiswa terhadap Tuberkulosis. Rekomendasi yang diberikan adalah peningkatan pengetahuan untuk pencegahan Tuberkulosis
\end{abstract}

Kata Kunci: Pengetahuan, Stigma, Tuberkulosis, 


\section{PENDAHULUAN}

Bakteri Mycobacterium tuberculosis merupakan penyebab terjadinya penyakit tuberkulosis yang sangat mudah menular dari individu satu ke individu lainya. Gejala yang sering muncul adalah batuk berdahak syang diikuti dengan gejala tambahan yaitu dahak bercampur darah, batuk darah, badan terasa lemas, sesak nafas, nafsu makan menurun, berat badan menurun, malaise/kelelahan, keluar keringat pada malam hari walau tanpa kegiatan fisik, badan teraba demam lebih dari satu bulan (Depkes RI, 2018)

Untuk menegakkan diagnosis $\mathrm{Tb}$ paru perlu dilakukan serangkaian pemeriksaan, diantaranya pemeriksaan dahak, pemeriksaan rogsen dada, dan tes kulit tuberkulin. Apabila dalam kurun waktu 5 tahun penderita dengan penyakit $\mathrm{Tb}$ paru tidak diobati dapat mengakibatkan kematian (Groenewald, Baird, Verschoor, Minnikin, \& Croft, 2014).

Kuman TB paru yang mudah sekali menyebar melalui droplet yang keluar bersama batuk penderita, hal ini membuat TB Paru termasuk dalam 10 penyebab kematian di dunia melebihi HIV/AIDS. Data yang dilansir dari WHO Global TB Report 2018 menyebut pengidap TBC di Indonesia pada tahun 2017 menyentuh angka 842 ribu kasus, yang mana angka itu telah menempatkan Indonesia di posisi tiga dalam daftar negara dengan kasus TBC tertinggi (Phillips, 2015).

Tahun 2018 tercatat kasus tuberkulosis di Indonesia sebanyak 1.017.290 kasus, berdasarkan survei prevalensi laki-laki memiliki prevalensi 3 kali lebih tinggi dibandingkan pada perempuan karena lakilaki lebih terpapar pada faktor resiko TBC seperti merokok, dan ketidakpatuhan minum obat. Provinsi yang mempunyai kasus tertinggi adalah Jawa Barat 186.809 kasus, Jawa Timur 151.878 kasus dan Jawa Tengah 132.565 kasus, sedangkan provinsi yang paling rendah terdapat di Kalimantan Utara dengan 2.733 kasus (Indonesian Ministry of Health, 2018).

Tingkat pengetahuan dan pandangan masyarakat mengenai TB paru masih sangat rendah. Pengetahuan yang kurang dapat memicu terjadinya peningkatan penularan dan kurang mampunya melakukan pencegahan tertularnya TB paru. Kurangnya pengetahuan juga dapat menyebabkan persepsi yang negatif terhadap penderita $\mathrm{Tb}$ dan berujung pada pengucilan penderita (Yani, Juniarti, \& Lukman, n.d.).

Stigma merupakan suatu pandangan negatif yang dimiliki oleh seseorang terhadap orang lain atau pemebrian label terhadap individu lain (Sari, 2018). Stigma dapat berasal dari idir sendiri ataupun dari lingkungan/sosial. Stigma sosial yang sering terjadi adalah dengan mengucilkan penderita dari kelompok, dan mendiskriminasi penderita dalam kegiatan sosial yang dilakukan (Kurspahić-Mujčić, Hasanović, \& Sivić, 2013). Stigma yang menyangkut dengan penyakit menular selalu berdampak negatif terhadap usaha pencegahan, prosedur pelayanan, dan kebijakan yang berkaitan dengan kesehatan pada penyakit tersebut (Novia Rizana, 2016).

Dengan pemberian label/stigma negatif terhadap individu yang menderita $\mathrm{Tb}$ paru mampu memicu sutu keadaan depresi, sehingga kemampuan untuk menerima asuhan keperawatan pada penderita $\mathrm{Tb}$ paru juga akan mengalami hambatan. Hal ini akan menurunakn kualitas hidup penderita $\mathrm{Tb}$ paru itu sendiri (Endria \& Yona, 2019). Perasaan malu dan tak berdaya akan muncul pada penderita $\mathrm{Tb}$ apabila lingkungan tidak memberikan dukungan yang positif, stigma negatif sering diberikan karena tb merupakan penyakit yang sangat mudah menular (Sari, 2018). 
Keadaan lingkungan Asrama rentan terjadi penularan penyakit $\mathrm{Tb}$. Hal ini dikarenakan satu ruangan kamar di huni oleh 3 - 4 orang mahasiswa, keadaan demografi yang mempunyai iklim lembab, dan keaadan hygiene mahasiswa. Hasil wawancara yang dilakukan terhadap 6 Penghuni asrama putra Universitas advent indonesia didapati bahwa mereka cenderung tidak ingin berinteraksi dengan penderita TB paru, karena menganggap penyakit TB paru merupakan penyakit yang mudah menular dan sulit disembuhkan. Sehingga mereka enggan untuk tinggal bersama dengan penderita TB paru.

Penelitian ini dilakukan untuk mengetahui tingkat pengetahuan mahasiswa asrama putra mnegenai TB paru, mengetahui stigma mahasiswa terhadap penderita $\mathrm{Tb}$ paru dan mengetahui apakah terdapat hubungan antara tingkat pengetahuan mengenai TBC dengan stigma mahasiswa terhadap penderita $\mathrm{Tb}$ paru.

\section{METODOLOGI}

Penelitian ini merupakan penelitian deskriptif korelasi dengan desain cross sectional (potong lintang). Penelitian dilakukan di ruang Aula Asrama Tingkat 1 dan 2 Universitas Advent Indonesia. Populasi pada penelitian ini adalah Mahasiswa asrama putra Universitas Advent Indonesia sebanyak 200 mahasiswa. Pengambilan sampel ditetapkan berdasarkan mahasiswa yang hadir pada acara penyuluhan kesehatan dan diambil secara total sampling, yaitu berjumlah 139 mahasiswa.

Pengumpulan data dilakukan dengan menggunakan kuesioner tingkat pengetahuan dan stigma yang diadopsi dari Pusat Krisis dan Pengembangan Komunitas (PKPK) fakultas Psikologi Universitas Airlangga. Pada kuesioner tingkat pengetahuan terdiri dari 9 pertanyaan dengan jawaban Ya dan Tidak, apabila jawaban benar akan mendapat nilai 1 dan apabila jawaban salah mendapat nilai 0 . Terdapat 10 pertanyaan pada kuesioner stigma mahasiswa terhadap penderita $\mathrm{Tb}$ paru, opsi jawaban menggunakan skala likert: sangat tidak setuju (1), tidak setuju (2), setuju (3), dan sangat setuju (4). Sedangkan hasil ukur dari stigma adalah memiliki stigma positif dan stigma negative terhadap penderita $\mathrm{Tb}$ paru.

Sebelum melakukan penelitian, proposal penelitian telah diajukan untuk uji etik pada KEPK FIK UNAI, telah dinyatakan layak etik dengan nomor surat etik 036/KEPKFIK/IC/XI/19. Setelah data terkumpul dilakukan analisa data menggunakan SPPS versi 20. Untuk data karakteristik, tingkat pengetahuan dan stigma menggunakan distribusi frekuensi, sedangkan untuk mengukur hubungan antara tingkat pengetahuan (variabel $\mathrm{x}$ ) dan stigma mahasiswa (variabel y) menggunakan uji korelasi spearman rho. Uji spearman rho dipilih karena distribusi data yang tidak normal.

\section{HASIL PENELITIAN}

Pemaparan hasil penelitian terdiri dari karakterisitik partisipan, sebaran tingkat pengetahuan mahasiswa terhadap TBC, stigma mahasiswa terhadap penderita $\mathrm{Tb}$ paru dan hubungan tingkat pengetahuan denga stigma mahasiswa.

Tabel 1. Karakterisitik Partisipan

\begin{tabular}{ccc}
\hline Karakteristik & Frekuensi & $(\%)$ \\
\hline Usia: & & \\
18 & 87 & 62.6 \\
19 & 30 & 21.6 \\
20 & 22 & 15.8 \\
Fakultas: & & \\
Ekonomi & 89 & 64 \\
IT & 9 & 6.5 \\
Teologi & 18 & 13 \\
Perawat & 23 & 16.5 \\
Total & 139 & 100 \\
\hline
\end{tabular}

Tabel 1 menunjukan data karakterisitik usia partisipan usia 18 tahun yaitu berjumlah 87 partisipan (62.6\%), usia 19 tahun sebnayak 30 partisipan $(21,6 \%)$ dan berusia 20 tahun 
sebanyak 22 partisipan (15,8 \%). Dengan partisipan terbanyak berasal dari fakultas Ekonomi sebanyak 89 partisipan (64\%), fakultas IT 9 partisipan (6.5\%), fakultas teologi 18 partisipan (13\%), dan fakultas perawat 23 partisipan (16.5\%). $100 \%$ partisipan merupakan mahasiswa tingkat 1 , yang baru beradaptasi dengan lingkungan asrama.

Kehidupan di asrama membuat mahasiswa saling berbagi ruangan untuk melakukan aktivitas sehari-hari. Hal seperti ini akan menjadi satu pemicu penyebaran Tuberkulosis apabila salah satu mahasiswa menderita Tuberkulosis.

Tabel 2. Tingkat Pengetahuan Mahasiswa

\begin{tabular}{cccc}
\hline $\begin{array}{c}\text { Tingkat } \\
\text { Pengetahuan }\end{array}$ & Frekuensi & $\%$ & $\begin{array}{c}\text { Rata- } \\
\text { rata }\end{array}$ \\
\hline Rendah & 62 & 44.6 & \\
Sedang & 71 & 51.1 & 70.5 \\
Tinggi & 6 & 4.3 & \\
Total & 139 & 100 & \\
\hline
\end{tabular}

Tingkat pengetahuan mahasiswa asrama putra Universitas Advent Indonesia mengenai tuberkulosis tersebar dari rendah, sedang, dan tinggi, adapun persentasenya adalah sebagai berikut: pengetahuan rendah sebanyak $44.6 \%$, pengetahuan sedang sebanyak $51.1 \%$ dan pengetahuan tinggi sebanyak $4.3 \%$. denganm nilai rata-rata $70.5 \%$ yang masuk dalam kategori tingkat pengetahuan sedang.

Tabel 3. Stigma Mahasiswa

\begin{tabular}{ccc}
\hline Stigma Mahasiswa & Frekuensi & $\%$ \\
\hline Stigma Positif & 50 & 36 \\
Stigma Negatif & 89 & 64 \\
Total & 139 & 100 \\
\hline
\end{tabular}

Data dari tabel 3 menunjukan sebaran stigma partisipan. 50 partisipan atau 36\% memiliki stigma positif terhadap penderita $\mathrm{Tb}$ paru, dominasi stigma negatif mahasiswa terhadap penderita Tb paru yaitu sebnayak 89 partisipan atau 64\%. Dapat disimpulkan bahwa mahasiswa asrama putra Universitas Advent
Indonesia memiliki stigma negatif dan enggan untuk bergaul/ menjaga jarak dengan penderita Tb paru. Hal yang paling dominan dari stigma mahasiswa adalah mereka merasa tidak nyaman apabila berada di dekat penderita $\mathrm{Tb}$ paru.

Uji korelasi dilakukan untuk mengetahui apakah terdapat hubungan antara tingkat pengratahuan dengan stigma mahasiswa. Data tingkat pengetahuan dan stigma mahasiswa mempunyai distribusi yang tidak normal, sehingga uji korelasi yang digunakan adalah uji korelasi Spearman Rho.

Tabel 4. Korelasi Tingkat Pengetahuan Terhadap Stigma mahasiswa

\begin{tabular}{ccc}
\hline Variabel & Korelasi & $\begin{array}{c}\text { Keeratan } \\
\text { Hubungan }\end{array}$ \\
\hline Tingkat & 0,009 & 0,219 \\
$\begin{array}{c}\text { Pengetahuan } \\
\text { Stigma } \\
\text { Mahasiswa }\end{array}$ & \\
\hline
\end{tabular}

Tabel 4 menunjukan adanya hubungan antara tingkat pengetahuan mahasiswa mengenai $\mathrm{Tb}$ paru dengan stigma mahasiswa pada penderita Tb Paru, dengan p value $0,009(<0,05)$ dengan tingkat keeratan hubungan lemah $(0,219)$. Hal ini mempunyai arti bahwa pengetahuan yang dimiliki oleh mahasiswa mengenai TBC mempunyai hubungan pada cara pandanganya terhadap penderita TBC.

\section{PEMBAHASAN}

Berdasarkan hasil dari penelitian ini maka dapat dilihat bahwa pengetahuan Mahasiswa asrama putra tentang TBC di Universitas Advent Indonesia Tahun 2019 sebagian besar berpengetahuan sedang dan Sebagian Mahasiswa Asrama Putra Universitas Advent Indonesia memiliki stigma Negatif.

Dari hasil penelitian yang didapat karakteristik partisipan untuk usia sebagian besar partisipan ber-usia 18 tahun, hal ini sesuai dengan usia 
mahasiswa lulus SMA. Dengan partisipan terbanyak berasal dari fakultas Ekonomi. Seluruh partisipan merupakan mahasiswa tingkat 1 yang baru mulai beradaptasi untuk tinggal bersama di asrama. Kehidupan berasrama yang menyebabkan mereka hidup berbaur dengan mahasiswa lain yang berasal dari berbagai daerah.

Hasil penelitian ini menunjukan lebih dari setengah partisipan yang bergabung dalam penelitian ini mempunyai tingkat pengetahuan sedang. Pengetahuan partisipan tentang TBC adalah kemampuan partisipan menjawab pertanyaan yang diberikan yaitu tentang pengertian, penyebab, tanda dan gejala serta penularan dan pencegahan TBC (Media, 2012). Hal ini sangat penting untuk diketahui, karena pengetahuan mendasari perilaku yang ditunjukan oleh masyarakat terhadap lingkungan dimana mereka tinggal (Ngurah, Mertha, \& Mayuni, 2014).

Dari hasil penelitian dapat dilihat distribusi frekuensi stigma mahasiswa yaitu sebagian besar dari partisipan memiliki stigma negatif terhadap penderita TBC, dan sebagian kecil dari partisipan memiliki stigma positif terhadap penderita TBC.

Stigma adalah proses sosial atau pengalaman pribadi yang ditandai dengan pengucilan, penolakan, celaan, atau devaluasi karena adanya anggapan sosial yang merugikan tentang individu maupun kelompok dikarenakan masalah kesehatan tertentu (Kipp et al, 2011). Menurut penelitian yang dilakukan Moya (2010), menyebutkan bahwa stigma dapat menyebabkan depresi, stress psikologi, ketakutan,dan menambah parahnya kondisi penyakit. Sedangkan berdasarkan hasil studi pendahuluan didapatkan bahwa mahasiswa asrama putra tidak mau bergaul dengan pasien TBC karena takut tertular penyakitnya. Mahasiswa asrama putra dominan memiliki stigma yang negatif terhadappenderita TBC yang ada di asrama diakibatkan karena kurnganya pengetahuan mengenai Tuberkulosis.
Apabila dilihat dari Tabel 4, yang menunjukan adanya hubungan yang signifikan antara Tingkat Pengetahuan Mahasiswa terhadap stigma mahasiswa. Dengan nilai p 0,009 < 0,05 mempunyai hubungan yang bersifat positif dengan tingkat keeratan hubungan rendah $(0,219)$, hal ini dapat disimpulkan bahwa pengetahuan yang dimiliki oleh mahasiswa tentang TBC merupakan sebagian faktor yang mempengaruhi stigma mahasiswa terhadap TBC.

Dengan demikian hasil penelitian tentang hubungan pengetahuan partisipan tentang TBC dengan stigma penderita TBC memiliki hubungan yang signifikan dimana semakin tinggi tingkat pengetahuan partisipan dalam mengetahui tanda dan gejala, penyebab, penularan, komplikasi, pengobatan dan pencegahan penyakit TBC maka akan semakin baik stigma nya terhadap penderita TBC.

Dikarenakan TBC merupakan salah satu penyakit yang mudah menular dilingkungan asrama makan diperlukan upaya untuk meningkatkan pengetahuan mahasiswa mengenai TBC. Melalui pendidikan dan promosi kesehatan di asrama untuk mencegah penyebaran TBC.

\section{KESIMPULAN}

Kesimpulan yang didapat dari penelitian ini adalah terdapat hubungan yang signifikan antara tingkat pengetahuan dengan stigma mahasiswa terhadap penderita TBC, semakin tinggi tingkat pengetahuan semakin positif stigma mahasiswa terhadap penderita TBC.

Penelitian ini diharapkan dapat menjadi dasar untuk mengembangkan studi yang lebih luas juga dapat menjadi sumber referensi untuk program pendidikan dan penyuluhan kesehatan pada klien TBC dan masyarakat yang tinggal bersama dengan penderita TBC. Terutama 
untuk mengatasi masalah stigma negatif yang dimiliki oleh orang lain terhadap penderita TBC. Sehingga stigma negatif dapat berkurang, penderita TBC tidak merasa dikucilkan serta mendapat dukungan utntuk mengikuti program pengobatan. Peingkatan pengetahuan dapat diberikan melalui pendidikan kesehatan di lingkungan asrama.

\section{DAFTAR PUSTAKA}

Depkes RI. (2018). InfoDatin Tuberculosis. Kementerian Kesehatan RI, 1. Retrieved from

https://www.depkes.go.id/article/view/18 030500005/waspadai-peningkatanpenyakitmenular.html\%0Ahttp://www.depkes.go.i d/article/view/17070700004/programindonesia-sehat-dengan-pendekatankeluarga.html

Endria, V., \& Yona, S. (2019). DEPRESI DAN STIGMA TB DENGAN KUALITAS HIDUP PASIEN TUBERKULOSIS PARU Depression and TB Stigma with the quality of life of patients with pulmonary tu- berculosis. Jurnal Riset Kesehatan NAsional, 03 No 1(2548-6144), 21-28. Retrieved from http://ojs.itekes-

bali.ac.id/index.php/jrkn/issue/view/11

Groenewald, W., Baird, M. S., Verschoor, J. A., Minnikin, D. E., \& Croft, A. K. (2014). Differential spontaneous folding of mycolic acids from Mycobacterium tuberculosis. Chemistry and Physics of Lipids, 180, 15-22. https://doi.org/10.1016/j.chemphyslip.20 13.12.004

Riskesdas 2018. Laporan Riskesdas Nasional 2018.

Kurspahić-Mujčić, A., Hasanović, A., \& Sivić, S. (2013). Tuberculosis related stigma and delay in seeking care after the onset of symptoms associated with tuberculosis. Medicinski Glasnik: Official Publication of the Medical
Association of Zenica-Doboj Canton, Bosnia and Herzegovina, 10(2), 272$277 . \quad$ Retrieved from http://www.ncbi.nlm.nih.gov/pubmed/23 892844

Media, Y. (2012). Pengetahuan, Sikap Dan Perilaku Masyarakat Tentang Penyakit Tuberkulosis (Tb) Paru Di Kecamatan Sungai Tarab, Kabupaten Tanah Datar Propinsi Sumatera Barat. Media of Health Research and Development, 21(2 Jun), $82-88$. https://doi.org/10.22435/mpk.v21i2Jun.1 08 .

Ngurah, I., Mertha, I., \& Mayuni, I. (2014). Pendidikan Kesehatan Tenantang Penularan Tuberkulosis Terhadap Stigma Masyarakat Wisatawan Tentang Tubekulosis. 82-89.

Novia Rizana, T. T. M. (2016). Pengetahuan, Sikap Dan Perilaku Keluarga Dalam Pencegahan Penularan Tuberkulosis Paru. Jurnal Ilmu Keperawatan, 4(2).

Phillips, J. A. (2015). Global Tuberculosis. In Workplace Health and Safety (Vol. 63). https://doi.org/10.1177/21650799156078 75

Sari, Y. (2018). Self Stigma of Pulmonary Tuberculosis Among Patients Seeking Treatment in Puskesmas Malingping. Media Ilmu Kesehatan, 7(1), 43-50.

Yani, D. I., Juniarti, N., \& Lukman, M. (n.d.). Pendidikan Kesehatan Tuberkulosis untuk Kader Kesehatan. 2(1). 